\title{
Effects of elevated temperatures on the embryonic development and corpus luteum activity in the Japanese long-fingered bat, Miniopterus schreibersii fuliginosus
}

\author{
T. A. Uchida, C. Inoue* and K. Kimura $\ddagger$ \\ Zoological Laboratory, Faculty of Agriculture, Kyushu University 46-06, Fukuoka 812, Japan
}

\begin{abstract}
Summary. Gravid female Japanese long-fingered bats were kept in captivity without hibernation at elevated temperatures $\left(23-25^{\circ} \mathrm{C}\right)$ in winter. The embryonic growth rate was accelerated and consequently parturition was advanced by a period equivalent to that of exclusion from hibernation as compared with that in the wild population. The corpus luteum became active, as indicated by an increase in the 'light' lutein cells in an experimental bat pregnant with a 15 -mm embryo, but was less active (more 'dark' cells) in 2 hibernating control bats with an implanting blastocyst.
\end{abstract}

\section{Introduction}

In mammals the gestation period is generally fixed for each species, but in some species of heterothermic bats it varies according to individual and/or geographical condition (Orr, 1970; Racey, 1982). The miniopterine bats widely inhabiting the Old World are a typical example of the geographical variation (Dwyer, 1963; Richardson, 1977; Wallace, 1978). In the Japanese longfingered bat, Miniopterus schreibersii fuliginosus, copulation, ovulation and fertilization occur in quick succession in autumn (Móri \& Uchida, 1980, 1981a, b) and the females enter into hibernation in a pregnant condition. However, embryogenesis proceeds very slowly because there is a delay of implantation and delayed development after implantation (Kimura \& Uchida, 1983). The rate of development after implantation can be affected by temperature (see Racey, 1981; Kimura \& Uchida, 1983). Kimura \& Uchida (1983) also commented briefly on the variation of activity of the corpus luteum between the preimplantation and the early placentation stage (before the beginning of hibernation to after arousal). The purpose of this study was to examine the effects of environmental temperatures on the developmental rate of the embryo and corpus luteum function.

\section{Materials and Methods}

Twenty-three pregnant long-fingered bats ( $M$. s. fuliginosus) collected at Ohse-dō Cave $\left(32 \cdot 5^{\circ} \mathrm{N}\right)$ in the Kumamoto Prefecture were used. Experiment 1 was designed, as follows, to examine differences in the developmental rate between the experimental group (Group E), kept without hibernation at elevated temperatures in the second half of hibernation, and the control group (Group C), kept under natural conditions (see Table 1). Bats of Group E were trained to feed on intact mealworms by their application with forceps to the lips of the bats, which then learnt to take

\footnotetext{
* Present address: Nagasakibana Parking Garden, Yamamoto Kanko Co., Ltd, Yamagawa-chō, Ibusuki-gun, Kagoshima Prefecture 891-05, Japan.

$\ddagger$ Present address: Laboratory of Animal Reproduction, Faculty of Textile Science and Technology, Shinshu University, Uede 386 , Japan.
}

(C) 1984 Journals of Reproduction \& Fertility Ltd 
them within a few days from a dish placed in the cage. Of 7 gravid females captured on 10 February 1982, about 40 days before arousal from hibernation, 1 was dissected on the same day, 5 (Bats E1E5) were caged in a wooden box $(23 \times 23 \times 25 \mathrm{~cm})$ placed in an incubator $\left(23-25^{\circ} \mathrm{C}\right.$, humidity $65 \%$ ) and fed on sufficient mealworms and water each day until the day for autopsy, and the remaining bat (Bat $\mathrm{C} 1$ ) was maintained under artificial hibernation in a refrigerator $\left(5-7^{\circ} \mathrm{C}\right)$ with only water for 40 days until killed as a control for Bat $\mathrm{E} 1$. The other control bats (Bats $\mathrm{C} 2-\mathrm{C} 6)$ were collected from the natural population simultaneously with the date of autopsy of each bat in Group E and killed at once.

In Exp. 2, the embryonic stages in Group E bats kept at an elevated temperature in the first half of hibernation were compared with those of Group $\mathrm{C}$ bats kept in artificial hibernation (see Table 2). Rectal temperatures were quickly measured within $2 \mathrm{sec}$ using a Tele-Thermometer $41 \mathrm{TD}$ and Electrode 507 (both from Yellow Springs Instrument Co., Inc., OH, U.S.A.), at about 13:00 and 19:00 $\mathrm{h}$ for Group $\mathrm{E}$ bats when they were resting and active respectively, and at 19:00 $\mathrm{h}$ for the Group $\mathrm{C}$ bats which were dormant.

The presumed age of each embryo in days was calculated as indicated by Kimura \& Uchida (1983). To determine the developmental stage, the uteri of Bats E6-E8, Cl and C7-C10, early in pregnancy, and a fetus of Bat E9 were fixed in Bouin's fluid, embedded in paraffin wax, and stained with Delafield's haematoxylin and eosin. The functional left ovaries (about $1.3 \times 1.5 \mathrm{~mm}$ ) of Bats E9, C9 and C10 in Exp. 2 were quickly removed and cut into two pieces in $3 \%$ glutaraldehyde in 0.2 M-phosphate buffer at $\mathrm{pH} 7 \cdot 4$, fixed with the same fixative for 4-5 h, and then washed with the same buffer, fixed further for $1 \mathrm{~h}$ in cold $1.3 \% \mathrm{OsO}_{4}$ buffered with the same buffer, dehydrated with acetone and embedded in Epon 812 . Thin sections $(\sim 60 \mathrm{~nm})$ were doubly stained with uranyl and lead acetate, and examined with an Hitachi HS-9 electron microscope $(75 \mathrm{kV})$. Thick sections $(1.5$ $\mu \mathrm{m}$ ) for light microscopy were stained with toluidine blue.

\section{Results}

\section{Experiment 1 (Table 1)}

A bat killed 10 February 1982, when Bats 1-5 of Group E and Bat C1 were captured, had an early implanted blastocyst. Bat E1, killed on $23 \mathrm{March}$ ( 40 days after the beginning of rearing at 23-

Table 1. Effects of elevated temperatures on the embryonic development in the second half of hibernation in Japanese long-fingered bats (Exp. 1)

\begin{tabular}{|c|c|c|c|c|c|}
\hline \multicolumn{3}{|c|}{ Group E $\left(23-25^{\circ} \mathrm{C}\right)$} & \multicolumn{2}{|r|}{ Group C (control) } & \multirow[b]{2}{*}{$\begin{array}{l}\text { Presumed age of } \\
\text { embryo or gestation } \\
\text { period (days) } \S\end{array}$} \\
\hline Bat* & $\begin{array}{c}\text { Date killed } \\
\text { (experimental period } \\
\text { in days) }\end{array}$ & $\begin{array}{l}\text { Size† of embryo } \\
\text { or young }\end{array}$ & Bat $\ddagger$ & $\begin{array}{c}\text { Stage or size }+ \\
\text { of embryo }\end{array}$ & \\
\hline E1 & 23 March 1982 & $10 \mathrm{~mm}$ (autopsied) & $\mathrm{Cl}$ & Implanted blastocyst & 159 \\
\hline E2 & 25 April 1982 (73) & $14 \mathrm{~mm}$ (aborted) & $\mathrm{C} 2-4$ & $6.5 \mathrm{~mm}$ (autopsied) & 192 \\
\hline E3 & 15 May 1982 (93) & $30 \mathrm{~mm}$ (aborted) & & & 212 \\
\hline E4 & 23 May $1982(101)$ & $31 \mathrm{~mm}$ (newborn) & $\mathrm{C} 5,6$ & $14 \mathrm{~mm}$ (autopsied) & 220 \\
\hline E5 & $1982(105)$ & $31 \mathrm{~mm}$ (newborn) & & & 224 \\
\hline
\end{tabular}

* Captured on 10 February 1982 and kept at elevated temperatures from the day after capture until killed.

$\dagger$ Shown by crown-rump length for normal embryos (E1 and C2-6), and by head and body length for aborted embryos (E2, E3) and newborn young (E4, E5).

$\ddagger$ Bat $\mathrm{Cl}$ was captured on 10 February 1982 and maintained under artificial hibernation in a refrigerator $\left(5-7^{\circ} \mathrm{C}\right)$ from the next day until autopsy (23 March 1982), and Bats C2-4 and C5 and C6 were collected from the field population on 25 April and 23 May 1982 respectively, and immediately dissected.

$\S$ Counted from the presumed day ( 15 October) of ovulation and fertilization. 
$25^{\circ} \mathrm{C}$ ) contained a 10-mm embryo, while Bat $\mathrm{C} 1$, kept in artificial hibernation for 40 days possessed an implanted blastocyst. Bats E2 and E3 aborted their embryos although those in Bats $\mathrm{C} 2-\mathrm{C} 4$ were only $6.5 \mathrm{~mm}$ in length. Bats E4 (Pl. 1, Fig. 1) and E5 gave birth within 4 days of each other while Bats C5 (Pl. 1, Fig. 1, inset) and C6 contained only 14-mm embryos. In the natural population, newborn young were collected on 3 July.

\section{Experiment 2 (Table 2)}

Bats E6 and E7 were killed on 1 December (after 7 days at $25^{\circ} \mathrm{C}$ ). Bats $\mathrm{C} 7$ and $\mathrm{C} 8$ were killed on the same day (after 7 days in artificial hibernation) and all 4 bats contained an implanting blastocyst. Bat E9 possessed a $15-\mathrm{mm}$ embryo (Pl. 1, Fig. 2), in contrast to Bat C9 in which the blastocyst was only just implanting (Pl. 1, Fig. 3). Bats E10, E11 and E12 all had measurable embryos while Bat $\mathrm{C} 10$ contained only an implanting blastocyst. In Group $\mathrm{E}$ bats the rectal temperature was about $24^{\circ} \mathrm{C}$ at rest and about $37^{\circ} \mathrm{C}$ when active, while in Group $\mathrm{C}$ it ranged between 6.5 and $12 \cdot 5^{\circ} \mathrm{C}$.

Table 2. Effects of an elevated temperature on the embryonic development in the first half of hibernation in Japanese long-fingered bats (Exp. 2)

\begin{tabular}{|c|c|c|c|c|c|}
\hline \multicolumn{3}{|c|}{ Group E $\left(25 \pm 0.5^{\circ} \mathrm{C}\right)$} & \multirow{2}{*}{\multicolumn{2}{|c|}{$\begin{array}{c}\text { Group C } \\
\text { (control, } 5-7^{\circ} \mathrm{C} \text { ) }\end{array}$}} & \multirow{3}{*}{$\begin{array}{c}\text { Presumed age } \\
\text { of embryo } \\
\text { (days)§ }\end{array}$} \\
\hline \multirow[b]{2}{*}{ Bat* } & \multirow{2}{*}{$\begin{array}{c}\text { Date killed } \\
\text { (experimental period } \\
\text { in days) }\end{array}$} & \multirow{2}{*}{$\begin{array}{l}\text { Stage or size } \dagger \\
\text { of embryo }\end{array}$} & & & \\
\hline & & & Bat $\ddagger$ & Stage of embryo & \\
\hline E6,E7 & 1 December 1982 & Implanting blastocyst & $\mathrm{C} 7, \mathrm{C} 8$ & Implanting blastocyst & 47 \\
\hline E8 & 6 December 1982 (12) & Primitive streak & & & 52 \\
\hline E9 & 10 January 1983 (47) & $15 \mathrm{~mm}$ (autopsied) & C9 & Implanting blastocyst & 87 \\
\hline E10 & 1 February $1983(69)$ & $24 \mathrm{~mm}$ (autopsied) & $\mathrm{ClO}$ & Implanting blastocyst & 109 \\
\hline E11 & 20 February $1983(88)$ & $33 \mathrm{~mm}$ (aborted) & & & 128 \\
\hline E12 & 27 February $1983(95)$ & $32 \mathrm{~mm}$ (aborted) & & & 135 \\
\hline
\end{tabular}

* Captured on 13 November 1982, kept at room temperature $\left(\sim 15^{\circ} \mathrm{C}\right)$ until 23 November 1982, and raised at an elevated temperature from the following day to the date killed.

$\uparrow$ Shown by crown-rump length for normal embryos (E9,E10), and by head and body length for aborted embryos (E11,E12).

¥ Captured and kept as in Group E but placed in artificial hibernation from 24 November 1982 to the date killed.

$\S$ Counted from the presumed day (15 October) of ovulation and fertilization.

\section{Ultrastructure of the corpus luteum}

In the corpus luteum of Bats $\mathrm{C} 9$ and $\mathrm{C} 10$ (kept for 47 and 69 days under artificial hibernation, respectively) with an implanting blastocyst, the lutein cells appeared to be of two types distinguishable by their different staining characteristics, i.e. 'light' and 'dark' cells. The 'dark' cells occupied a larger area than did the 'light' cells (Pl. 2, Fig. 4, inset). The 'light' cells contained a round nucleus, well developed smooth endoplasmic reticulum with packed tubular cisternae and several lysosomes, whereas the 'dark' cells contained an irregularly shaped dense nucleus, ubiquitous smooth endoplasmic reticulum with expanded cisternae, several autophagocytic bodies and a moderate amount of lipid droplets with high electron-density (Pl. 2, Fig. 4). In the corpus luteum of Bat E9 (kept for 47 days at $25^{\circ} \mathrm{C}$ ), which had a $15-\mathrm{mm}$ embryo, both types of cell were recognized, but the areas covered by each were similar (Pl. 2, Fig. 5, inset). The 'light' cells were characterized by highly developed smooth endoplasmic reticulum with meshed tubular cisternae, membranous whorls and abundant lipid droplets with low electron-density, but the 'dark' cells were similar to those Group C bats (P1. 2, Fig. 5). 


\section{Discussion}

Retardation or acceleration in the rate of embryonic development by environmental temperatures in heterothermic bats, which is a peculiar phenomenon in mammals (Racey, 1981, 1982), has been examined experimentally in brown bats, Myotis myotis (Eisentraut, 1937) and pipistrelles, Pipistrellus pipistrellus (Racey, 1969, 1973), and reported for horseshoe bats, Rhinolophus hipposideros (Kolb, 1950), pipistrelles, P. pipistrellus (Racey \& Swift, 1981) and tomb bats, Taphozous longimanus (Krishna \& Dominic, 1982) under natural conditions.

In the miniopterine bats, in which gestation is interrupted by hibernation, the gestation period varies with latitude, even within a given species, and has a tendency to lengthen with increasing latitude (Dwyer, 1963; Wimsatt, 1969; Richardson, 1977). The gestation period is about 10 months in $M$. schreibersii inhabiting the south of France $\left(45^{\circ} \mathrm{N}\right)$ (Peyre \& Herlant, 1967), about 8.7 months in $M . s$. fuliginosus from Japan $\left(32.5^{\circ} \mathrm{N}\right.$ ) (Uchida, 1957), about 8 months in the Australian $M$. schreibersii $\left(30^{\circ} \mathrm{S}\right)$ (Wallace, 1978) and $M$. s. natalensis from South Africa $\left(25^{\circ} 50^{\prime} \mathrm{S}\right)$ (van der Merwe, 1980 ). In the Australian $M$. australis, it is about $5 \frac{1}{2}$ months at $31^{\circ} S$ (Dwyer, 1963), $3 \frac{1}{2}-4$ months at $15^{\circ} \mathrm{S}$ (Baker \& Bird, 1936) and $4 \frac{1}{2}-5$ months at $5^{\circ} \mathrm{N}$ (Medway, 1971).

In Bats E4 and E5 of Exp. 1, which were collected about 40 days before arousal from hibernation and raised at $23-25^{\circ} \mathrm{C}$, parturition took place after 220 and 224 days of presumed gestation, respectively and was earlier by about 40 days than under natural conditions. The gestation period therefore seemed to be reduced by a period similar to that when the bats were removed from hibernation. We therefore conclude that the geographical variations in the gestation

\section{PLATES 1 AND 2}

Abbreviations: A, alimentary canal; $\mathrm{Ab}$, autophagocytic body; $\mathrm{Au}$, antimesometrial uterine wall; B, blastocyst cavity; C, cerebellum; D, diencephalon; Dc, 'dark' lutein cell; E, endoderm; F, femur; H, heart; L, liver; Lc, 'light' lutein cell; Ld, lipid droplet; Lu, lung; Ly, lysosome; M, mitochondrion; Mc, mesencephalon; Mo, medulla oblongata; Mu, mesometrial uterine wall; Mw, membranous whorl of smooth endoplasmic reticulum; $\mathbf{N}$, nucleus; $\mathrm{P}$, primitive amniotic cavity; $\mathrm{S}$, spinal cord; Se, smooth endoplasmic reticulum; T, telencephalon; $\mathrm{Tb}$, trophoblast; $\mathrm{U}$, uterine lumen; $\mathrm{V}$, vertebra.

\section{PLATE 1}

Fig. 1. A $31-\mathrm{mm}$ young born on $23 \mathrm{May}$ by Bat E4 kept at $23-25^{\circ} \mathrm{C}$ for 101 days in Exp. 1. Inset: a 14-mm fetus obtained on the same day from Bat C5 under natural conditions is well contrasted with the above.

Figs 2 and 3. Light micrographs showing a comparison of developmental stages between bats from the experimental and control groups killed on the same day (10 January) in Exp. 2. Fig. 2. Sagittal section of a 15-mm fetus from Bat E9 raised at $25^{\circ} \mathrm{C}$ for 47 days. Fig. 3. Median section through an implanting blastocyst from Bat $\mathrm{C} 9 \mathrm{kept}$ in artificial hibernation at $5-7^{\circ} \mathrm{C}$.

\section{PLATE 2}

Figs 4 and 5. Electron micrographs showing a comparison of cells of the corpus luteum from bats in the control and experimental groups in Exp. 2. Fig. 4. In Bat C9, a 'light' lutein cell has a round nucleus, well developed smooth endoplasmic reticulum with packed tubular cisternae and several lysosomes, whereas 'dark' lutein cells contain an irregularly shaped dense nucleus, ubiquitous smooth endoplasmic reticulum with expanded cisternae, several autophagocytic bodies and a moderate amount of lipid droplets with high electron-density. Inset: light micrograph of a part of the corpus luteum showing a larger area occupied by the predominant 'dark' cells than by the 'light' ones. Fig. 5. In Bat E9, a 'light' cell has highly developed smooth endoplasmic reticulum with meshed tubular cisternae, membranous whorls and abundant lipid droplets with low electron-density, but 'dark' cells show the same features as do those in Bat C9. Inset: light micrograph of a part of the corpus luteum showing a nearly even area occupied by each type cell. 
PLATE 1
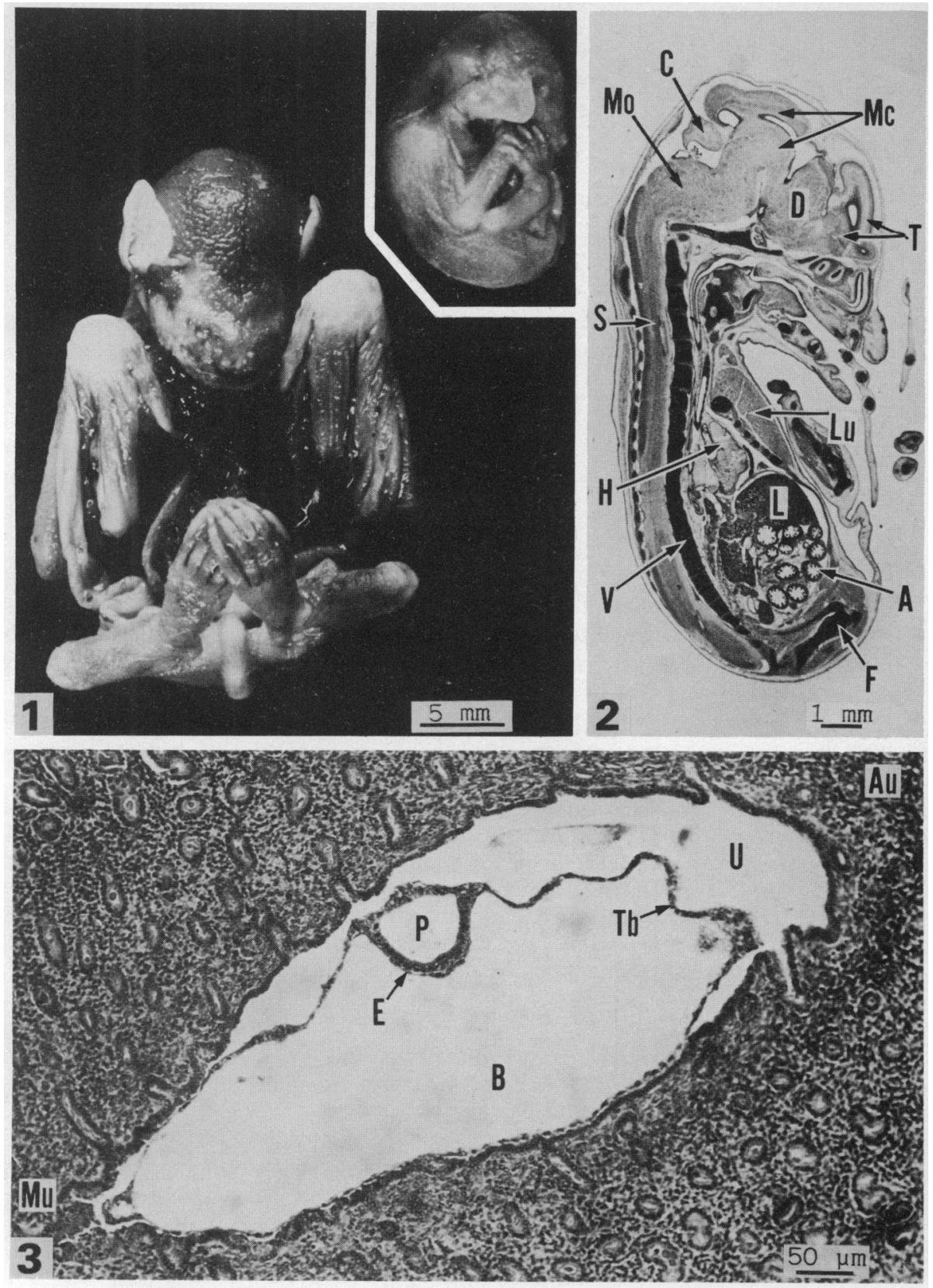

(Facing p, 442) 


\section{PLATE 2}

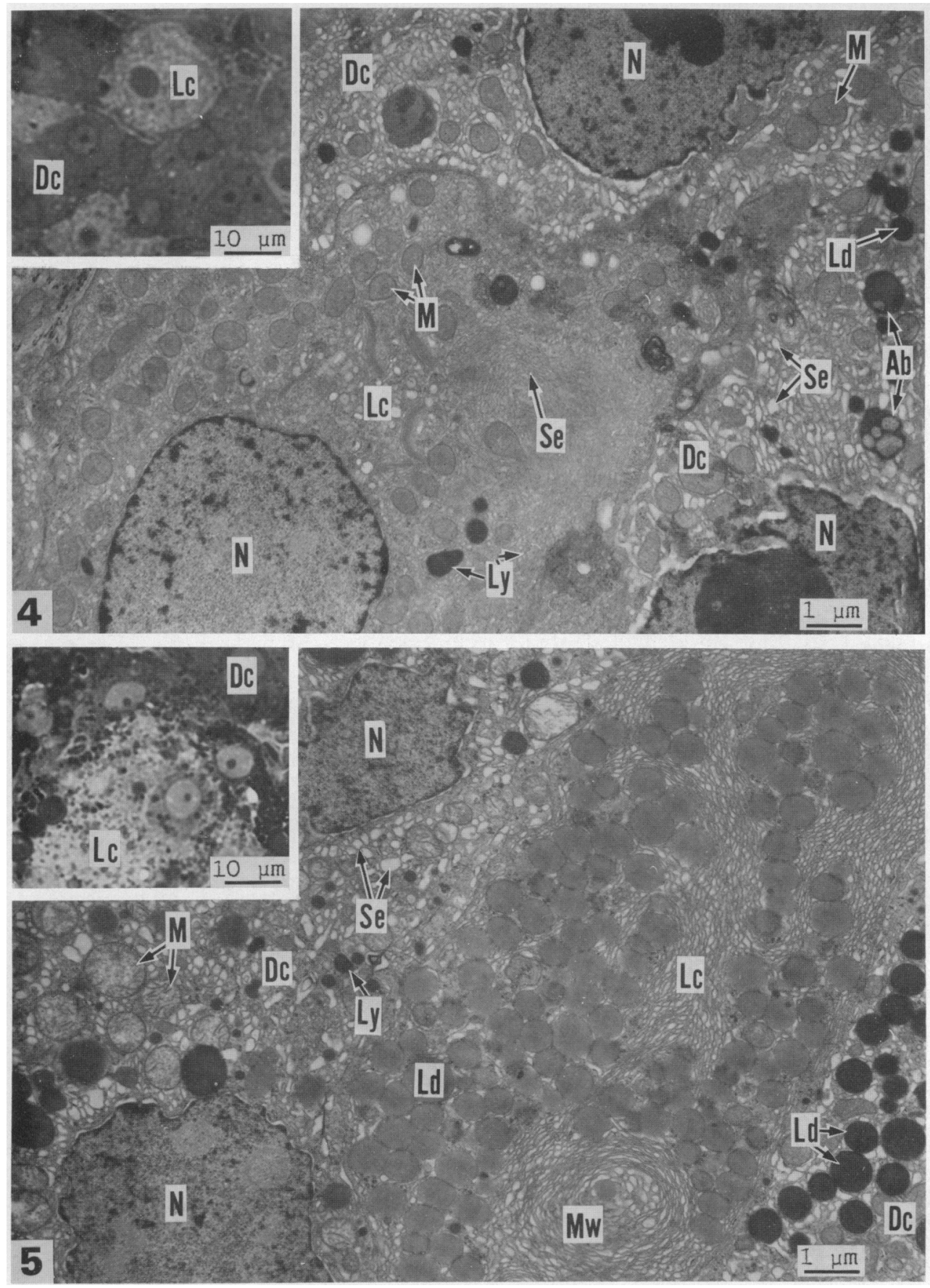


period are due to differences in the length of retarded embryonic development during hibernation, resulting from disparities in environmental factors especially ambient temperatures. However, delayed development has been reported for the California bat, Macrotus californicus, which does not hibernate; despite ample food supplies elevated temperatures failed to shorten the period during which the embryonic growth was retarded (Burns, 1981).

'Light' and 'dark' cells were observed in the corpora lutea of 1 experimental and 2 control bats. The main differences between 'light' and 'dark' cells in the bats and in other mammals resides in the contour and density of the nucleus (Crombie et al., 1971; Nett, McClellan \& Niswender, 1976), in the form and arrangement of sER (Christensen \& Gillim, 1969; Umo, 1975; Nett et al., 1976) and in the presence and absence of autophagocytic bodies (Crombie et al., 1971; Nett et al., 1976; Paavola, 1977). Whether the phenomenon is real or artefactual is still uncertain (Crombie, Burton \& Ackland, 1971) because some investigators are of the opinion that immersion fixation such as we used will produce such 'light' and 'dark' effects (Christensen \& Gillim, 1969; Paavola, 1977). However, both cell types appear to exhibit different states of the same cell and 'dark' cells at a later stage than the 'light' cells may represent the beginning of luteal regression (Crombie et al., 1971). The characteristics of the 'light' cells in Bat $E$ were consistent with those of cells involved in active steroidogenesis (Bjersing, 1967; Enders, 1973), while those of the 'dark' cells indicate less steroidogenic activity. This conclusion supports the observations of Kimura \& Uchida (1983) on bats obtained directly from natural populations.

We thank Dr T. Mōri of this Laboratory for technical advice; Professor E. W. Jameson, Jr, Department of Zoology, University of California for comments on the manuscript; and Professor T. Kanaseki, Faculty of Medicine, Kyushu University for useful suggestions.

\section{References}

Baker, J.R. \& Bird, I.F. (1936) The seasons in a tropical rain forest (New Hebrides). Part 4. Insectivorous bats (Vespertilionidae and Rhinolophidae). J. Linn. Soc. Lond. 40, 143-161.

Bjersing, L. (1967) On the ultrastructure of granulosa lutein cells in the porcine corpus luteum. With special reference to endoplasmic reticulum and steroid hormone synthesis. Z. Zellforsch. mikrosk. Anat. 82, 187-211.

Burns, J.M. (1981) Aspects of endocrine control of delay phenomena in bats with special emphasis on delayed development. J. Reprod. Fert., Suppl. 29, 61-66.

Christensen, A.K. \& Gillim, S.W. (1969) The correlation of fine structure and function in steroid-secreting cells, with emphasis on those of the gonads. In The Gonads, pp. 415-488. Ed. K. W. Mckerns. NorthHolland, Amsterdam.

Crombie, P.R., Burton, R.D. Ackland, N. (1971) The ultrastructure of the corpus luteum of the guinea-pig. Z. Zellforsch. mikrosk. Anat. 115, 473-493.

Dwyer, P.D. (1963) Reproduction and distribution in Miniopterus (Chiroptera). Aust. J. Sci. 25, 435-436.

Eisentraut, M. (1937) Die Wirkung niedriger Temperaturen auf die Embryonalentwicklung bei Fledermäusen. Biol. Z Zbl. 57, 59-74.

Enders, E.C. (1973) Cytology of the corpus luteum. Biol. Reprod. 8, 158-182.

Kimura, K. \& Uchida, T.A. (1983) Ultrastructural observations of delayed implantation in the Japanese long-fingered bat, Miniopterus schreibersii fuliginosus. J. Reprod. Fert. 69, 187-193.
Kolb, A. (1950) Beitrage zur Biologie einheimisher Fledrmause. Zool. Jahrb. Abt. Syst. Ökol. Geogr. Tiere 78, 547-572.

Krishna, A. \& Dominic, C.J. (1982) Differential rates of fetal growth in two successive pregnancies in the emballonurid bat, Taphozous longimanus Hardwicke. Biol. Reprod. 27, 351-353.

Medway, Lord (1971) Observations of social and reproductive biology of the bent-winged bat Miniopterus australis in northern Borneo. J. Zool., Lond. 165, 261273.

Mōri, T. \& Uchida, T.A. (1980) Sperm storage in the reproductive tract of the female Japanese long-fingered bat, Miniopterus schreibersii fuliginosus. J. Reprod. Fert. 58, 429-433.

Mōri, T. \& Uchida, T.A. (1981a) Ultrastructural observations of fertilization in the Japanese long-fingered bat, Miniopterus schreibersii fuliginosus. J. Reprod. Fert. 63, 231-235.

Mōri, T. \& Uchida, T.A. (1981 b) Ultrastructural observations of ovulation in the Japanese long-fingered bat, Miniopterus schreibersii fuliginosus. J. Reprod. Fert. 63, 391-395.

Nett, T.M., McClellan, M.C. \& Niswender, G.D. (1976) Effects of prostaglandins on the ovine corpus luteum: blood flow, secretion of progesterone and morphology. Biol. Reprod. 15, 66-78.

Orr, R.T. (1970) Development: prenatal and postnatal. In Biology of Bats, Vol. 1, pp. 217-231. Ed. W. A. Wimsatt. Academic Press, New York. 
Paavola, L.G. (1977) The corpus luteum of the guinea pig. Fine structure at the time of maximum progesterone secretion and during regression. Am.J. Anat. 150, 565-604.

Peyre, A. \& Herlant, M. (1967) Ovo-implantation différée et déterminisme hormonal chez le Minioptère, Miniopterus schreibersi K. (Chiroptère). C. $r$. Séanc. Soc. Biol. 161, 1779-1782.

Racey, P.A. (1969) Diagnosis of pregnancy and experimental extension of gestation in the pipistrelle bat, Pipistrellus pipistrellus. J. Reprod. Fert. 19, 465-474.

Racey, P.A. (1973) Environmental factors affecting the length of gestation in heterothermic bats. J. Reprod. Fert., Suppl. 19, 175-189.

Racey, P.A. (1981) Environmental factors affecting the length of gestation in mammals. In Environmental Factors in Mammalian Reproduction, pp. 199-213. Eds D. Gilmore \& B. Cook. MacMillan, London.

Racey, P.A. (1982) Ecology of bat reproduction. In Ecology of Bats, pp. 57-104. Ed. T. H. Kuntz. Plenum Press, New York.

Racey, P.A. \& Swift, S.M. (1981) Variations in gestation length in a colony of pipistrelle bats (Pipistrellus pipistrellus) from year to year. J. Reprod. Fert. 61, 123-129.

Richardson, E.G. (1977) The biology and evolution of the reproductive cycle of Miniopterus schreibersii and $M$. australis (Chiroptera: Vespertilionidae). J. Zool., Lond. 183, 353-375.

Uchida, T.A. (1957) Fertilization and hibernation in bats. Heredity, Tokyo 11, 14-17. [In Japanese.]

Umo, I. (1975) Effect of prostaglandin $F_{2 \alpha}$ on the ultra structure and function of sheep corpora lutea. $J$. Reprod. Fert. 43, 287-292.

van der Merwe, M. (1980) Delayed implantation in the Natal clinging bat Miniopterus schreibersi natalensis (A. Smith, 1834). In Proc. 5th Int. Bat Res. Conf., pp. 113-123. Eds D. E. Wilson \& A. L. Gardner. Lubbock, Texas.

Wallace, G.I. (1978) A histological study of the early stages of pregnancy in the bent-winged bat (Miniopterus schreibersii) in north-eastern New South Wales, Australia (302'S). J. Zool., Lond. 185, 519-537.

Wimsatt, W.A. (1969) Some interrelationships of reproduction and hibernation in mammals. Symp. Soc. exp. Biol. 23, 511-549.

Received 11 October 1983 